\title{
Improving Students' Problem Solving Ability and Mathematical Communication through the Application of Problem Based Learning
}

\author{
Hayatun Nufus* \& Mursalin \\ Department of Mathematics Education, Universitas Malikussaleh, Aceh Utara, Indonesia \\ ${ }^{*}$ Corresponding Author: h.nufus1988@gmail.com
}

(Received 5 February 2020; Revised 16 May 2020; Accepted 10 July 2020)

\section{ABSTRACT}

The purpose of this study was to determine the improvement of students' mathematical problem solving and communication skills using problem-based learning better than ordinary learning; to determine the interaction between learning and early mathematical abilities to increase students' mathematical problem solving and communication skills; to find out how the process of answers made by students in solving problems in problem-based learning and ordinary learning. This type of research is quasi-experimental. The population in this study were all grade VII students of SMP Lhokseumawe who were accredited and the samples were randomly selected, namely: SMPN 10 consisted of class VII-4 (experimental class) and class VII-2 (control class), SMPN 11 Lhokseumawe consisted of class VII- 3 (experimental class) and class VII-1 (control class). Data analysis was performed using two-way ANOVA. The results of this study indicate that there is an increase in the problem-solving ability and mathematical communication of students using problem-based learning better than students who receive regular learning; there is no interaction between learning and the level of students 'ability to increase students' problem-solving abilities and mathematical communication; the process of solving the problem of students' answers to learning using problem-based learning is better than ordinary learning.

Key Words: problem-based learning, problem solving abilities, students' mathematical communication

\section{INTRODUCTION}

Mathematics is one of the subjects taught at every level of education both in elementary, junior high, high school and university, the science that underlies the development of scientific and technological advances so that mathematics is seen as a structured and integrated science, the knowledge of patterns and relationships, and science. about how to think about making sense of the world around you. This is emphasized within the Government of the Republic of Indonesia through the Regulation of the Minister of National Education (Permendiknas) Number 22 of 2006 concerning Content Standards for Primary and Secondary Education Units (Depdiknas, 2006) that mathematics underlies the development of technological advances, has an important role in various disciplines, and advances human thinking, mathematics is given early in school to equip children with the ability to think logically, analytically, systematically, critically, creatively, and the ability to work together. All these abilities are important provisions and assets needed by children in pursuing a life in a future that is full of challenges and changes rapidly.

However, it is unfortunate that today many students have difficulty learning mathematics. Students do not have the desire to try and think at high levels to find solutions to every difficulty found in learning mathematics but instead, as much as possible, always avoid the difficulties they experience, as a result of low student learning outcomes in mathematics. One of the reasons for the low learning outcomes of students' mathematics is because many students consider mathematics to be difficult to learn and mathematical characteristics are abstract so that students consider mathematics to be a frightening specter, reinforced by Sriyanto (2007) who states that mathematics is often considered a frightening specter and tends to be considered difficult lesson by most of the students. Russefendi (1991) also added that mathematics for children is generally a subject that is not liked, is considered a difficult and complicated science, and Abdurrahman (2003) said that of the various fields of study taught in schools, mathematics is the field of study that is considered the most difficult. difficult by students, both those who do not have learning difficulties and even more so for students who have difficulty learning. 
Many factors influence students to think mathematics is difficult to learn, one of which is the lack of students' ability in problem-solving and mathematical communication. Even though the 2006 KTSP has emphasized explicitly the objectives of learning mathematics, one of which aspects of problem-solving skills and mathematical communication are very important components that must be possessed by students. Problem-solving is the process of applying previously acquired knowledge into new, unfamiliar situations so that students are more challenged and motivated to learn it. Hudojo (1988) states that problem solving is a very essential thing in teaching mathematics, because (1) students become skilled at selecting relevant information, then analyze it and finally examine the results, (2) intellectual satisfaction will arise from within, (3) the intellectual potential of students increases. However, the facts in the field show that students' problem-solving abilities are still low, one of which is based on the results of the Program for International Student Assessment (PISA) test. Indonesia is one of the PISA participating countries. The distribution of students' mathematical abilities in PISA is level 1 (as many as $49.7 \%$ of students), level 2 (25.9\%), level 3 (15.5\%), level 4 (6.6\%), and levels 5 - 6 (2,3\%). At level 1, students are only able to solve math problems that require one step. Proportionally, out of every 100 junior high school students in Indonesia, only about 3 students reach levels 5 - 6 .

In addition to problem-solving skills, students also need to master mathematical communication skills because in education it is inseparable from the role of communication. Baroody (1993) explains there are two reasons why communication in students' mathematics plays an important role and needs to be improved in learning mathematics. firstly mathematics as a language, meaning that mathematics is not only a tool for finding patterns, solving problems, or drawing conclusions, but mathematics is also a valuable tool for communicating various ideas in a clear, precise, and accurate manner. Second, mathematics learning as a social activity, meaning that mathematics is a social activity in learning, mathematics is also a vehicle for interaction between students, and also communication between teachers and students.

However, the facts in the field based on the results of observations of the teacher in the process of implementing mathematics learning, show that the teacher is only looking for convenience and is always being pursued by a target time to complete each subject regardless of the competence possessed by students, the questions given by the teacher are The questions in the textbook result in students not understanding mathematical problems related to real-life around students, and the examples of problems given are first resolved by a demonstration then students are given questions according to these examples, the teacher still thinks that doing so will improve students' abilities even though on the contrary students only imitate what the teacher does because in solving these problems students only do as exemplified by the teacher without the need to use their abilities in solving right. The teacher in assessing a problem only looks at the result and rarely pays attention to the problem-solving process towards the final result. This can be seen from the survey results of each question that was tested on each student, it was found that the process of completing student answers was not different, so that students could not increase their mathematics learning activities to improve their development of abilities.

Addressing the problems that arise in school mathematics education, it is necessary to find a learning model that can improve students' mathematical solving abilities. According to Arends (2008), the instructional objectives of problem-based learning are to help students develop investigative skills and problem-solving skills, provide experiences of adult roles, and allow students to gain confidence in their abilities, to think and become good learners. independently. Based on this opinion, it appears that problem-based learning has the aim of helping students develop problem-solving skills. In addition to improving problem-solving abilities, the problem-based learning model can also improve students' mathematical communication skills. Piaget (Arend, 2008) said problem-based learning where teachers provide various situations (problems) so that children can experiment, try various things to see what will happen, manipulate objects, manipulate symbols, ask questions and find their answers, compile what is found and compare it with the findings of other students.

According to Arends (2008), problem-based learning has the essence of presenting various real problematic conditions, which will be solved by students through various investigations and investigations. So that the role of the teachers is to present various contextual problems to motivate students, arouse student enthusiasm, increasing student learning activities, learning focused on solving problems so that students are interested in learning, discovering concepts, and sharing knowledge between students and students. with the teacher.

Based on the description above, the problem that will be resolved and sought for a solution is "What is the increase in students' problem solving and mathematical communication skills through the application of problem-based learning $(\mathrm{PBM})$ ?"

\section{RESEARCH METHOD}

To answer these problems, the type of research used is quasi-experimental. The design chosen was the pretest-posttest control group design. In this design, the research subjects were grouped randomly. The experimental group was given problem-based learning $(\mathrm{X})$. The control group with learning is usually carried out at the school, then each is given a pretest and posttest (O). The population in this study were all accredited junior high school students in the city of Lhokseumawe. As for the samples of this study are schools that have a middle level. According to Saragih (2010), middle-level schools have heterogeneous academic abilities, from the lowest to the highest that can be represented. Of the nine schools that had an intermediate level, two schools were taken with a sampling unit of two classes from each school. By randomly selected SMP Negeri 10 and SMP Negeri 11 Lhokseumawe as research samples.

Data in the form of scores obtained from tests of students' problem-solving abilities and mathematical communication were grouped according to the learning groups. The relationship between the independent, dependent, and control variables is presented in the Wainer model in Table 1. 
Table 1. Weiner's table about the relationship between independent, dependent, and control variables.

\begin{tabular}{|c|c|c|c|c|c|}
\hline \multicolumn{2}{|c|}{ Measured ability } & \multicolumn{2}{|c|}{ Math problem solving } & \multicolumn{2}{|c|}{$\begin{array}{l}\text { Mathematical communication } \\
\text { skills }\end{array}$} \\
\hline \multicolumn{2}{|c|}{ Learning approaches } & PBM (A) & $\begin{array}{l}\text { Conventional } \\
\text { (B) }\end{array}$ & PBM (A) & $\begin{array}{l}\text { Conventional } \\
\text { (B) }\end{array}$ \\
\hline \multirow{4}{*}{$\begin{array}{l}\text { Students' initial } \\
\text { ability (C) }\end{array}$} & High & KPACT & KPBCT & KKACT & KKBCT \\
\hline & Modium & KPACS & KPBCS & KKACS & KKACS \\
\hline & Low & KPACR & KPBCR & KKACR & KKBCR \\
\hline & & KPA & KPB & KKA & KKB \\
\hline
\end{tabular}

Description:

KPACT means the problem solving ability with problem-based learning of students who have high initial abilities.

\section{RESULTS AND DISCUSSION}

Descriptively the results of research relating to the improvement of students' mathematical problem-solving and communication abilities in problem-based learning and mathematical communication are shown in Tables 2 and 3.

Table 2. Average Gain of Problem Solving Ability for PBM Group and PMB Group Based on Students' Mathematical Ability

\begin{tabular}{|c|c|c|c|c|c|}
\hline \multirow{2}{*}{ Teaching } & \multirow{2}{*}{ Students' Mathematical Abilities } & \multicolumn{4}{|c|}{ Problem solving skill } \\
\hline & & $\bar{X}$ & Std & Min & $\operatorname{Max}$ \\
\hline \multirow{4}{*}{$\mathrm{KPA}$} & High (9) & 0,29367 & 0,043831 & 206 & 357 \\
\hline & Medium (26) & 0,24946 & 0,062792 & 171 & 429 \\
\hline & Low (5) & 0,23460 & 0,073663 & 147 & 323 \\
\hline & Total (40) & 0,25755 & 0,062666 & 147 & 429 \\
\hline \multirow{4}{*}{$\mathrm{KPB}$} & High (9) & 0,20644 & 0,065660 & 125 & 348 \\
\hline & Medium (25) & 0,19560 & 0,050348 & 118 & 286 \\
\hline & Low (6) & 0,21817 & 0,032096 & 118 & 273 \\
\hline & Total (40) & 0,20142 & 0,051450 & 118 & 348 \\
\hline
\end{tabular}

Table 3. The Average Gain of Mathematical Communication Ability in the PBM Group and the PMB Group Based on Students' Mathematical Ability

\begin{tabular}{|c|c|c|c|c|c|}
\hline \multirow{2}{*}{ Approachs } & \multirow{2}{*}{ Students' Mathematical Abilities } & \multicolumn{4}{|c|}{ Mathematical Communication Skills } \\
\hline & & $\overline{\bar{X}}$ & Std & Min & $\operatorname{Max}$ \\
\hline \multirow{4}{*}{ KKA } & High (9) & 0,56822 & 0,195504 & 0,364 & 1,000 \\
\hline & Medium (26) & 0,44512 & 0,131836 & 0,182 & 0,750 \\
\hline & Low (5) & 0,35220 & 0,065990 & 0,267 & 0,429 \\
\hline & Total (40) & 0,46120 & 0,154167 & 0,182 & 1,00 \\
\hline \multirow{4}{*}{ KKB } & High (9) & 0,48156 & 0,056040 & 0,417 & 0,583 \\
\hline & Medium (25) & 0,37612 & 0,130830 & 0,154 & 0,636 \\
\hline & Low $(6)$ & 0,28717 & 0,063060 & 0,231 & 0,400 \\
\hline & Total (40) & 0,38650 & 0,123933 & 0,154 & 0,636 \\
\hline
\end{tabular}

Based on the Table 2. above, it is found that the increase in student problem-solving abilities using problem-based learning (KPA) has an average value and standard deviation for the high group 0.29367 and 0.043831 , moderate 0.24946 and 0.062792 , low 0.23460 and 0.073663 . Meanwhile, to increase problem-solving abilities using ordinary learning, namely: the high group has a value of 0.20644 and 0.065660 , the medium group is 0.19560 and 0.050348 , the low group is 0.21817 and 0.032096. Based on the increase in the average problem-solving ability, problem-based learning is higher than ordinary learning.

Table 3 describes an increase in students 'mathematical communication skills in problem-based learning and ordinary learning, it is found that an increase in students' mathematical communication skills using problem-based learning (KKA) has an average value and standard deviation for high abilities 0.56822 and 0.195504 , the medium ability is 0.44512 and 0.131836 , the low ability is 0.35220 and 0.065990 . Whereas for the category of mathematical communication skills using ordinary learning, namely: high ability has a value of 0.48156 and 0.056040 , the medium ability is 0.37612 and 0.130830 , the low ability is 0.28717 and 0.063060 . The average increase in the two learning groups, namely the average increase in communication skills with problem-based learning is higher than ordinary learning.

To test the significance of the correctness of the above conclusions, it is necessary to calculate statistical tests. Statistical testing of the hypotheses in this study used two-way analysis of variance (ANOVA) techniques. The ANAVA test results are presented in Tables 4 and 5. 
Table 4. Two-way ANOVA Test Summary to Gain Students' Problem Solving Ability

Tests of Between-Subjects Effects

Dependent Variable:Gain

\begin{tabular}{|c|c|c|c|c|c|c|}
\hline Source & Type III Sum of Squares & $\mathrm{df}$ & Mean Square & $\mathrm{F}$ & Sig. & Partial Eta Squared \\
\hline Corrected Model &, $082^{\mathrm{a}}$ & 5 &, 016 & 5,098 &, 000 &, 256 \\
\hline Intercept & 2,928 & 1 & 2,928 & 912,186 &, 000 &, 925 \\
\hline Learning Factors &, 037 & 1 &, 037 & 11,581 & 001 &, 135 \\
\hline Student abilities &, 010 & 2 &, 005 & 1,586 & ,212 & 041 \\
\hline $\begin{array}{l}\text { Learning Factors * Students' } \\
\text { abilities }\end{array}$ & 009 & 2 &, 004 & 1,357 &, 264 &, 035 \\
\hline Error & ,238 & 74 & ,003 & & & \\
\hline Total & 4,533 & 80 & & & & \\
\hline Corrected Total & 319 & 79 & & & & \\
\hline
\end{tabular}

a. $\mathrm{R}$ Squared $=, 256$ (Adjusted R Squared $=, 206$ )

Table 5. Summary of Two-Way ANOVA Test to Gain Mathematical Communication Ability

Tests of Between-Subjects Effects

Dependent Variable:Gain

\begin{tabular}{|c|c|c|c|c|c|c|}
\hline Source & $\begin{array}{c}\text { Type III Sum of } \\
\text { Squares }\end{array}$ & $\mathrm{df}$ & Mean Square & $\mathrm{F}$ & Sig. & Partial Eta Squared \\
\hline Corrected Model &, $424 \mathrm{a}$ & 5 &, 085 & 5,172 & 000 & ,259 \\
\hline Intercept & 9,443 & 1 & 9,443 & 575,854 &, 000 & ,886 \\
\hline Learning Factors &, 073 & 1 &, 073 & 4,451 & 038 & 057 \\
\hline Student abilities &, 311 & 2 &, 156 & 9,484 &, 000 & ,204 \\
\hline Learning Factors * Students' abilities &, 001 & 2 & 001 &, 037 & ,964 & 001 \\
\hline Error & 1,214 & 74 & 016 & & & \\
\hline Total & 16,009 & 80 & & & & \\
\hline Corrected Total & 1,638 & 79 & & & & \\
\hline
\end{tabular}

a. $\mathrm{R}$ Squared $=, 259$ (Adjusted R Squared $=, 209)$

Based on Table 4, the results of hypothesis testing are presented. The first hypothesis is that the increase in the problem-solving ability of students who are taught by problem-based learning is better than ordinary learning. Based on Table 4, it can be seen that $\mathrm{F}$ on the learning factor (KPA and KPB) is 11.581 with a significance value of 0.001 smaller than the 0.05 significance level so that Ho is rejected. In other words, there is an increase in math problem-solving abilities between students who are given problem-based learning (PBM) compared to students who are given regular learning (PMB). Thus, it can be concluded that the increase in the problem-solving ability of students who use problem-based learning (PBM) is better than students who learn normally (PMB). The second hypothesis is that there is an interaction between learning and students 'initial mathematics ability to increase students' problem-solving abilities. Based on Table 4, it is found that for learning factors related to student ability, the $\mathrm{F}$ value is 1.357 with a significance value of 0.264 , greater than the significance level of 0.05 , so that HO is accepted. So it can be concluded that there is no interaction between learning (KPA and KPB) with students 'initial abilities (high, medium, and low) on improving students' problem-solving abilities. In other words, the increase in problem-solving abilities is caused by differences in learning used not because of students' mathematical abilities. Graphically, this interaction can be seen in Figure 1.

The third hypothesis is that the increase in students' mathematical communication skills taught by problem-based learning is better than students who are taught using ordinary learning. Based on Table 5 , it is found that the $\mathrm{F}$ value for the learning factors (KKA and KKB) is 4.451 with a significance of 0.038 which is smaller than the 0.05 significance level. Therefore, the null hypothesis which states that there is no increase in mathematical communication skills between students who are given PBM compared to students who are given PMB is rejected. In other words, there is an increase in mathematical communication skills between students who are given PBM compared to students who are given PMB. So it can be concluded that the increase in mathematical communication skills of students who are given PBM is better than students who are given PMB.

The fourth hypothesis is that there is an interaction between learning and students 'initial mathematical abilities towards improving students' mathematical communication skills.Based on Table 5, it is found that for the interaction between the approach factor and the ability, an $\mathrm{F}$ value of 0.037 is obtained with a significance value of 0.964 , this value is greater than the 0.05 significance level. Therefore, the null hypothesis which states that there is no interaction between learning and students 'mathematical abilities on the improvement of students' mathematical communication skills can be accepted. In other words, the increase in communication skills is caused by differences in the learning used not because of the students' mathematical abilities. Graphically, this interaction can be seen in Figure 2. 


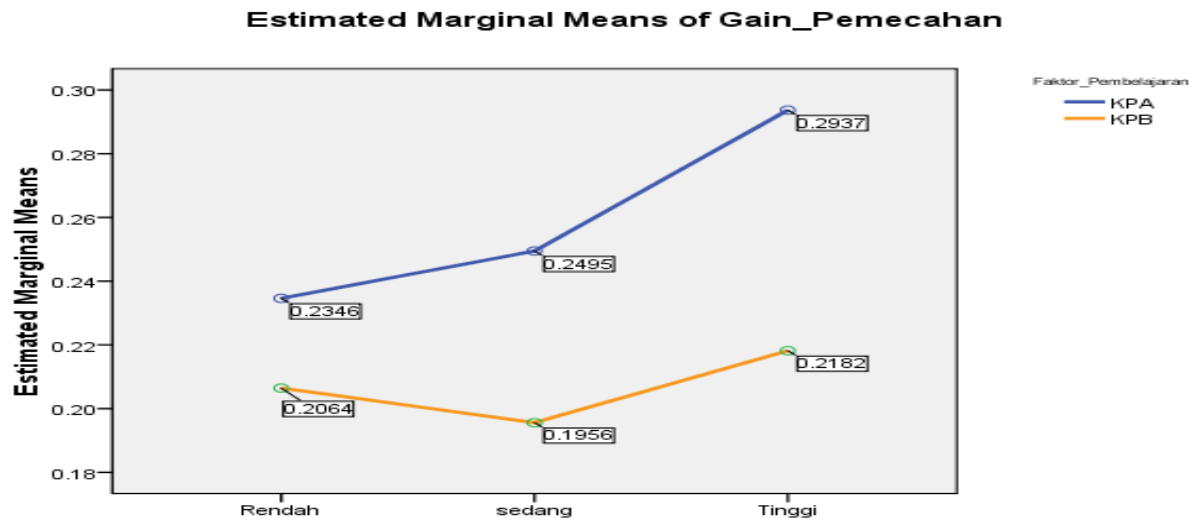

Figure 1. The Interaction between Learning Factors and Students 'Mathematical Ability Factors on the Improvement of Students' Problem Solving Ability

Estimated Marginal Means of Gain_Komunikasi
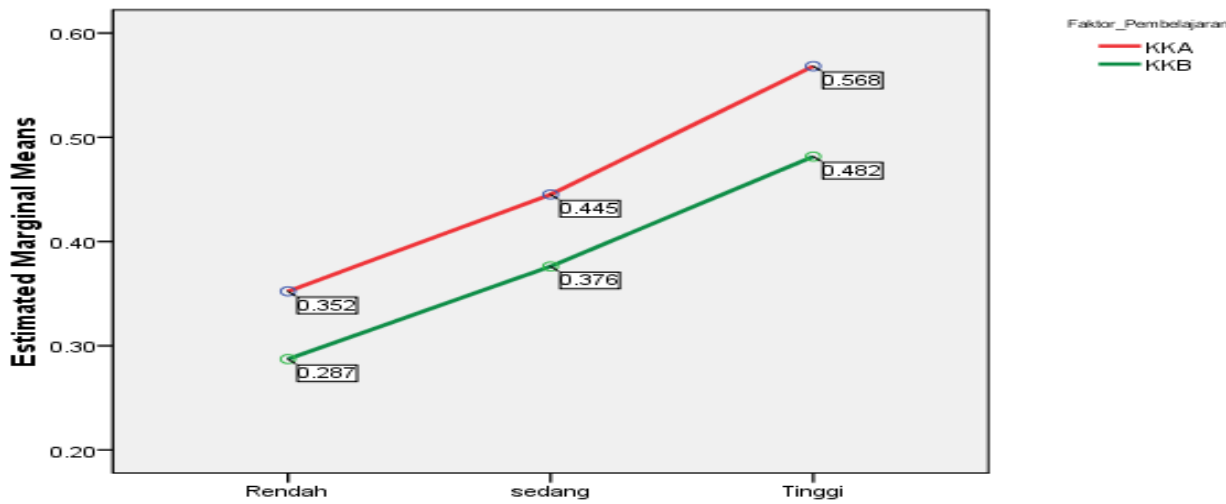

Figure 2. The Interaction between Learning Factors and Students' Mathematical Ability Factors on the Improvement of Mathematical Communication Skills

Based on the research results obtained above, the following will describe the factors involved in this research, namely the learning factors to increase students' mathematical problem solving and communication abilities. This research shows that the problem solving and mathematical communication skills of students taught by problem-based learning are better than ordinary learning. These findings are reinforced by the findings of Marzuki (2012) in his research which shows that the differences in problem solving and mathematical communication abilities of students who are given problem-based learning are better than students who are taught directly. Theoretically, the characteristics of problem-based learning have advantages compared to ordinary learning. Here are some of the advantages of problem-based learning based on the characteristics of the learning. First, problem-based learning (PBM) organizes learning around questions and social problems that are important to students and society. The problems given are real to students and do not have simple answers. According to Arends (2008) questions or problems must meet the following criteria: namely authentic, clear, easy to understand and in accordance with the learning objectives. Unlike the case with ordinary learning, according to Hadi (2005) states that several things that characterize mathematics learning in Indonesia so far are teacher-centered learning, teachers deliver lessons using the lecture method while students record them in notebooks.

Second, problem-based learning requires the teacher to motivate students to carry out investigations to find authentic solutions to the proposed problems. Whereas in ordinary learning, the teacher acts as a learning resource. Third, collaboration, in problem-based learning, student discussion groups are formed. Each group is given a student activity sheet (LAS) which contains authentic problems related to students' mathematical problem solving and communication abilities. Problem-based learning conditions students to complete learning tasks in the form of joint problem solving between students and their friends, in pairs or in small groups. Students discuss or ask questions with their friends, and consult with teachers. On the other hand, in normal learning, students act as recipients of full information from the teacher and students work together individually in solving problems. The methods of solving the questions depend on how the teacher solves the questions so that the students' mindset is formed according to the form of the teacher only. Thus, the active role of students is very small in learning.

The results of hypothesis testing show that the increase in problem solving and mathematical communication skills of students taught by problem-based learning is better than students taught with ordinary learning. The results also showed that there was no interaction between learning and students 'mathematical students' ability to improve students 'problem solving abilities and students' mathematical communication. Based on the difference in the average problem-solving ability, 
it appears that students with the high KAM category get "greater benefits" from problem-based learning (PBM) with a score difference of 0.08666 while the difference in scores for students in the moderate KAM category is 0.069 and the KAM category is low 0,06508, as well as students' mathematical communication skills also showed the same thing, namely with a score difference of 0.08666 while the difference in scores for students in the moderate KAM category was 0.069 and the KAM category was 0.06508 . This means that there is no joint increase that is contributed by the learning and initial mathematical abilities of students to students' mathematical problem solving abilities. These findings are in line with research conducted by Napitupulu (2011) and Khayroiyah (2012) which shows that there is no interaction between learning factors and students 'initial ability factors on students' mathematical problem solving abilities.

\section{CONCLUSION}

The improvement of students' problem-solving abilities taught through problem-based learning (PBM) is better than students who are taught using ordinary learning. Improved mathematical communication skills of students who are taught problem-based learning $(\mathrm{PBM})$ is better than students who are taught with ordinary learning. There is no interaction between learning and students' initial mathematical ability to increase problem-solving abilities. There is no interaction between learning and students' initial mathematical abilities towards improving mathematical communication skills.

\section{REFERENCES}

Abdurrahman, M. (2003). Pendidikan Bagi Anak berkesulitan Belajar. Jakarta: PT Rineka Cipta.

Arends, R. I (2008). Learning to Teach. Buku Dua. Edisi Ketujuh. Yogyakarta:Pustaka Pelajar.

Baroody, A.J. (1993). Problem Solving, Reasoning, and Kominicating, $k$-8. Healping Children Thing Mathematically. New York : Merril, an Inprint of Macmillan Publishing, Company.

Depdiknas. (2006). Peraturan Menteri Pendidikan Nasional Nomor 22 Tahun 2006 Tenntang Standar Isi Sekolah Menengah Pertama. Jakarta: Depdiknas

Hadi, S. (2005) Pendidikan matematika Realistik dan Implementasinya . Banjarmasin : Tulip.

Hudojo, H. (2001). Pengembangan Kurikulum dan Pembelajaran Matematika. Malang: Universitas Negeri Malang.

Marzuki. (2012) Perbedaan Kemampn Komampuan Pemecahan Masalah dan Komunikasi Matematika Antara Pembelajaran Berbasis Masalah Dengan Pembelajaran Langsung. Tesis. Medan : PPs Unimed. (Tidak dipublikasi)

Napitupulu, E. (2011). Pengaruh Pembelajaran Berbasis Masalah atas Kemampuan Penalaran dan Pemecahan Masalah Matematis serta Sikap Terhadap Matematika Siswa Sekolah Menengah Atas. Disertasi. Bandung: PPs UPI Bandung. (Tidak dipublikasi)

Khayroiyah, S. (2012). Analisis Perbedaan Kemampuan Pemecahan Masalah dan Penalaran Matematika Siswa dengan Menggunakan Model Pembelajaran Berbasis Masalah dan Pembelajaran Biasa Pada Siswa SMP. Tesis. Medan : PPs Unimed. (Tidak dipublikasi)

Saragih, S. (2007). Mengembangkan Kemampuan Berpikir Logis dan Komunikasi Matematika Siswa Sekolah Menengah Pertama Melalui Pendekatan Matematika Realistik. Disertasi tidak dipublikasikan. Bandung : Program Pascasarjana UPI Bandung.

Sriyanto, (2007). Strategi Sukses Menguasai Matematika. Jakarta: Indonesia cerdas.

Ruseffendi. (1991). Pengantar Kepada Guru Mengembangkan Kompetensinya dalam Mengajar Matematika untuk Meningkatkan CBSA. Bandung: Tarsito. 